\title{
PENINGKATAN KUALITAS JERAMI PADI SEBAGAI PAKAN SAPI POTONG MELALUI AMONIASI MENGUNAKAN UREA DI DESA TIMBUOLO TENGAH PROVINSI GORONTALO
}

\author{
Fahrul Ilham $^{1 *}$, Muhammad Sayuti ${ }^{1}$, Tri Ananda Erwin Nugroho ${ }^{1}$ \\ ${ }^{1}$ Program Studi Peternakan, Fakultas Pertanian, Universitas Negeri Gorontalo, Gorontalo, Indonesia \\ *Penulis Korenspondensi: fahrulilham82@ung.ac.id
}

\begin{abstract}
Abstrak
Amoniasi jerami merupakan metode memperbaiki nutrisi jerami padi dengan merusak ikatan ligninhemisellulosa sehingga mudah dicerna mikroba rumen. Tujuan kegiatan ini adalah meningkatkan pengetahuan dan keterampilan warga desa Timbuolo Tengah, Kabupaten Bone Bolango, Provinsi Gorontalo membuat jerami padi amoniasi. Metode yang digunakan pemberian teori dan simulasi kepada warga sasaran, dilanjutkan praktek langsung membuat jerami padi amoniasi. Kegiatan ini dilakukan 21 hari sejak persiapan, pelaksanaan pelatihan, evaluasi kualitas fisik dan kimia jerami padi amoniasi. Bahan pembuatan jerami padi amoniasi adalah jerami padi, urea, molases, Microbacter Alfaafa (MA)11, dan air. Evaluasi kualitas fisik/organoleptik (warna, bau, tekstur, suhu, $\mathrm{pH}$, dan keberadaan fungi) dan kimia (air, protein, lemak, serat kasar, Bahan Ekstrak Tanpa Nitrogen (BETN), dan abu) dilakukan di Laboratorium Nutrisi dan Makanan Ternak Universitas Hasanuddin. Selama kegiatan pelatihan, warga desa cukup antusias mengikuti semua tahap kegiatan sejak persiapan hingga evaluasi dengan tingkat capaian $100 \%$. Hasil pengujian fisik diperoleh warna coklat muda/kecoklatan, bau amoniak, tekstur halus, Ph 7,8, Suhu $43,66{ }^{\circ} \mathrm{C}$, dan ditemukan sedikit fungi/jamur. Hasil analisis proksimat diperoleh kadar air 8,09\%, protein 5,65\%, lemak 1,99\%, serat kasar 33,60\%, Bahan Ekstrak Tanpa Nitrogen (BETN) 31,66\%, dan abu 27\%.
\end{abstract}

Kata Kunci: Jerami Padi, Amoniasi

\begin{abstract}
Straw ammoniation is method of improving rice straw nutritional quality by damaging ligninhemisellulosa bond so it is more easily digested by rumen microbe. This activity aims to improve the knowledge and skill in making rice straw ammoniation of Middle Timbuolo villagers in Botupingge subdistrict, Bone Bolango regency, Gorontalo province. The method used is giving theories and simulation to the target group members and continued by practicing directly in making ammoniation. This activity is carried out for 21 days with main ingredients are rice straw, urea, molasses, Microbacter Alfaafa (MA) -11,water. Physical quality evaluation was done after 21 days observing the color, odor, texture, temperature, $p H$, and the presence of fungi, and performing the proximate analysis of chemical evaluation (water, protein, fat, coarse fiber, Nitrogen Free Extract (NFE) and ash) at Nutrition and Feed Laboratory of Hasanuddin University. During the training, the villagers are enthusiastic with achievement level is $100 \%$. The physical test results are color is brownish, smells like ammonia, has fine texture, $\mathrm{PH} 7.8$, temperature $43.66^{\circ} \mathrm{C}$, and found little fungi. Proximate analysis results are water content $8.09 \%$, protein $5.65 \%$, fat $1.99 \%$, coarse crude fiber $33.60 \%$, Nitrogen Free Extract $31.66 \%$ and ash $27 \%$.
\end{abstract}

Keywords: Rice Straw, Ammoniation

\section{PENDAhuluan}

Desa Timbuolo Tengah merupakan desa yang permukaan buminya sebagian besar merupakan pegunungan dan sebagian lagi berada di tepi sungai Bone, sungai terbesar dan terpanjang di Kabupaten Bone Bolango. Mata pencaharian penduduk di desa ini sebagian besar adalah bertani dan beternak sapi, kambing, maupun ayam. Bangsa sapi yang banyak dipelihara di Desa Timbuolo Tengah adalah sapi bali, namun minimnya pakan yang tersedia menyebabkan pertumbuhan dan perkembangan tubuhnya tidak optimal. Dalam rangka mengatasi kekurangan pakan terutama dimusim kemarau, salah satu cara yang dapat dilakukan adalah dengan memanfaatkan limbah pertanian jerami padi sebagai sumber pakan. Jerami padi adalah hasil samping dari usaha pertanian tanaman padi berupa daun, tangkai dan batang tanaman setelah produk utamanya berupa bulir-bulir padi (gabah) dipisahkan. Jerami padi dapat dimanfaatkan untuk berbagai produk yang bermanfaat, dan salah satunya 
dapat dipergunakan sebagai pakan ternak ruminansia seperti sapi, kambing, dan kerbau.

Berdasarkan hasil kajian, satu hektar sawah yang ditanami padi sawah mampu menghasilkan jerami padi sekitar 12 - 15 ton untuk satu kali panen atau 4-5 ton bahan kering tergantung pada lokasi dan jenis varietas tanamannya (Bata, 2008). Jerami padi masih dapat digunakan sebagai pakan ternak ruminansia sebab masih memiliki kandungan nutrisi yang dibutuhkan oleh ternak meskipun lebih rendah dari hijauan segar. Komposisi kimiawi jerami padi IR 64 adalah bahan kering 91,29\%, protein kasar 4,10\%, serat kasar $33,35 \%$, lemak kasar 3,88\%, abu 21,35\% dan bahan organik 69,94\% (Preston, 2005). Hasil survei inventarisasi limbah pertanian di Jawa dan Bali yang dilakukan Fakultas Peternakan Universitas Gadjah Mada dan Direktorat Bina Program tahun 1982 mengasumsikan rataan produksi jerami padi sawah sebesar 3,86 ton bahan kering/ha/panen, dan padi ladang 2,76 ton bahan kering/ha/panen (Anonimous, 1982).

Pemanfaatan jerami padi sebagai pakan ternak di Indonesia masih kurang maksimal yaitu hanya berkisar antara 31-39\%, untuk industri 7-16\% dan sisanya 36$62 \%$ dibiarkan sebagai limbah (Hidanah, 2007). Hal ini disebabkan kandungan serat kasar yang cukup tinggi dan kadar protein yang rendah, sehingga ternak ruminansia tidak mampu untuk memenuhi kebutuhan hidup pokok bahkan untuk bereproduksi. Selain kandungan proteinnya rendah, jerami padi juga mempunyai nilai kecernaan bahan kering dan bahan organik yang rendah, yakni berturut-turut antara 34$52 \%$ dan 42-59\% (Winugroho et al., 1983), sehingga kemampuan konsumsi bahan kering oleh ternak ruminansia hanya $2 \%$ dari bobot badan (Utomo et al., 1998). Jerami padi juga memiliki kandungan silika yang cukup tinggi dan bersama-sama dengan lignin semakin memperkuat dan memperkeras dinding sel tanaman, sehingga membuat dinding sel tersebut tidak dapat dicerna oleh mikroba rumen (Van Soest, 1982).

Meningkatkan daya cerna jerami padi sekaligus nilai nutrisinya dapat dilakukan dengan beberapa metode, diantaranya secara fisik, kimiawi, dan biologis (Martawidjaja, 2003). Amoniasi jerami merupakan metode biologis yang sering dilakukan untuk memperbaiki kualitas nutrisi jerami padi dengan cara merusak ikatan lignin-hemisellulosa sehingga lebih mudah dicerna oleh mikroba dalam rumen. Mikroba rumen dapat mencerna pakan yang memiliki serat tinggi hingga menjadi asam lemak terbang (Volatile Fatty Acids = VFA's) seperti asam asetat, asam propionat, asam butirat, asam valerat serta asam isobutirat dan asam isovalerat yang selanjutnya akan diserap melalui dinding rumen dan dimanfaatkan sebagai sumber energi oleh ternak. Sebaliknya biomas mikroba yang meninggalkan rumen dapat menjadi sumber protein bagi ternak ruminansia
Mikrobia rumen dapat mencerna serat pakan, memanfaatkan nitrogen non protein dan menjadi sumber protein bagi induk semang (Achmadi, 2012). Urea mampu meningkatkan protein kasar ransum karena urea mengandung sekitar $45 \%$ nitrogen atau equivalen dengan $284 \%$ protein kasar. Penambahan urea sebanyak $0,99 \%$ dalam ransum mampu meningkatkan kadar protein kasar ransum dari 15,99\% menjadi 17,85\% (Puastuti Dan Mathius, 2008). Berdasarkan hal tersebut maka pemberian urea terhadap jerami padi dapat meningkatkan energi dan protein sehingga produktivitas sapi potong dapat meningkat.

Kegiatan ini bertujuan meningkatkan pengetahuan dan keterampilan warga desa Timbuolo Tengah di Provinsi Gorontalo membuat jerami padi amoniasi. Volume jerami padi di Timbuolo Tengah relatif sedikit namun daerah sekitar Timbuolo Tengah seperti Kecamatan Kabila dan Suwawa produksinya berlimpah terutama saat panen dan hanya dibakar apabila sudah menumpuk banyak. Amoniasi jerami padi diharapkan dapat mengatasi kekurangan pakan saat musim kemarau sebab pakan lebih awet dan nilai nutrisinya juga bertambah. Pada kegiatan ini jerami padi yang telah dikumpulkan dari area persawahan diberi urea yang telah dilarutkan dalam air bersama molases dan Microorganism Alfaafa (MA)-11 selanjutnya difermentasi dalam ruang terbuka selama 21 hari. Sebelum diberikan ke ternak, terlebih dahulu dilakukan evaluasi baik fisik dan kimia untuk mengetahui kualitas jerami padi yang telah diamoniasi.

\section{BAHAN DAN METODE}

Pengabdian Pada Masyarakat (PPM) pembuatan jerami padi amoniasi ini dilaksanakan di Kecamatan Botupingge, tepatnya di Desa Timbuolo Tengah Kabupaten Bone Bolango selama 21 hari. Peserta kegiatan adalah warga desa dari Desa Timbuolo Tengah dan Timbuolo Timur Kecamatan Botupingge Kabupaten Bone Bolango.

Metode yang digunakan dalam melakukan pemberdayaan warga desa didahului dengan pemberian teori kepada warga desa yang menjadi sasaran dan diikuti dengan praktek secara langsung pembuatan jerami padi amoniasi. Bahan utama jerami padi amoniasi yang dibuat adalah jerami padi, urea, molases, Microbacter Alfaafa (MA)-11, dan air. Keseluruhan bahan selain jerami padi dicampur dalam ember yang berisi air. Selanjutnya campuran disiram diatas permukaan tumpukan jerami padi di setiap lapisan dengan cara dipercik sedikit demi sedikit hingga merata. Setelah dipadatkan, tumpukan jerami dibiarkan selama 3 minggu menunggu proses fermentasi oleh mikroba selesai.

Evaluasi terhadap kualitas fisik (organoleptik) dilakukan setelah 21 hari meliputi warna, bau, tekstur, $\mathrm{pH}$, suhu, dan keberadaan fungi. Data yang diperoleh dikategorikan berdasarkan Aprintasari, dkk (2012) yaitu warna dengan kategori coklat, coklat muda, 
kuning, dan kuning muda; tekstur dengan kategori sangat halus, halus, kasar, sangat kasar; bau dengan kategori asam/amoniak, tidak berbau, khas jerami, apek; jamur dengan kategori sangat banyak, banyak, sedikit, dan tidak ada.

Evaluasi terhadap kualitas kimia jerami padi amoniasi meliputi analisis proksimat yang dilakukan di Laboratorium Nutrisi dan Makanan Ternak Universitas Hasanuddin. Komponen nutrisi yang diamati adalah kandungan air, protein, lemak, serat kasar, Bahan Ekstrak Tanpa Nitrogen (BETN), dan abu.

\section{HASIL DAN PEMBAHASAN}

\subsection{Bahan Pembuatan Jerami Padi Amoniasi}

Amoniasi jerami padi adalah serangkaian proses yang dilakukan untuk menambah kandungan nutrisi jerami padi dan kecernaannya sehingga lebih efisien dikonsumsi oleh ternak ruminansia (sapi potong). Amoniasi jerami padi dengan menggunakan urea $\left(\mathrm{NH}_{2} \mathrm{CONH}_{2}\right)$ dapat meningkatkan kandungan nitrogen (McDonald et al., 2002), palatabilitas, konsumsi dan kecernaan pakan (Ahmed et al., 2002).

Beberapa bahan yang digunakan untuk membuat jerami padi amoniasi adalah:

- Jerami Padi. Berdasarkan data dari BPS Bone Bolango (2016) luas panen padi sawah dan ladang di Kabupaten Bone Bolango adalah 4096,5 ha dan 143 ha sehingga bila diestimasi produksi Bahan Kering (BK) jerami padi di Kabupaten Bone Bolango adalah 21752,42 dan 759,33 ton dan merupakan potensi pakan yang berlimpah. Kriteria jerami padi yang diamoniasi adalah yang sudah dikeringkan selama satu hari sehingga kadar airnya berkurang. Jumlah jerami padi yang digunakan adalah 100 karung gabah atau $\pm 2000 \mathrm{~kg}$. Jerami padi diperoleh dari areal persawahan di Kabupaten Bone Bolango

- Urea. Urea adalah pupuk kimia mengandung Nitrogen (N) berkadar tinggi. Urea berbentuk butirbutir kristal berwarna putih dengan rumus kimia $\mathrm{NH}_{2} \mathrm{CONH}_{2}$. Urea mudah larut dalam air dan sangat mudah menghisap air (higroskopis). Urea mengandung unsur hara $\mathrm{N}$ sebesar $46 \%$ dengan pengertian setiap $100 \mathrm{~kg}$ mengandung $46 \mathrm{Kg}$ Nitrogen, Moisture 0,5\%, Kadar Biuret 1\%, ukuran 1-3,35MM 90\% Min serta berbentuk Prill (Pusri, 2018). Jumlah Urea yang digunakan adalah 5\% dari total berat jerami padi yang akan diamoniasi

- Molases. Molases (tetes tebu) merupakan hasil samping dari pengolahan tebu menjadi gula yang masih mengandung gula dan asam-asam organik cukup tinggi. Kandungan sukrosa dalam molases adalah 48-55\% (Sebayang, 2006) sehingga sering digunakan peternak untuk sumber makanan mikrorganisme dalam proses pembuatan pakan fermentasi.

- Microbacter Alfaafa (MA)-11. Merupakan kultur campuran dari berbagai mikroorganisme fermentatif dan sintetik yang menguntungkan. MA11 mengandung bakteri selulotik, proteolitik, amilolitik, dan bakteri penambat $\mathrm{N} 2$ yang mampu mencerna selulose, pati, gula, protein, lemak khususnya bakteri sehingga pakan yang difermentasi meningkat kecernaannya.

- Air. Air yang digunakan berfungsi untuk memperbanyak volume dan melarutkan urea bersama molases dan MA-11 sehingga lebih mudah dipercik ke jerami padi yang akan diamoniasi.

\subsection{Proses Pembuatan}

Pembuatan jerami padi amoniasi didahului dengan menyiapkan alat dan bahan yang akan digunakan. Alat yang digunakan antara lain timbangan $50 \mathrm{~kg}$ untuk menimbang jerami padi, timbangan $2 \mathrm{~kg}$ untuk menimbang urea dan molases, ember untuk mencampur molases, air dan urea. Langkah-langkah pembuatan jerami padi amoniasi adalah jerami dihamparkan diatas lantai ruang untuk proses amoniasi jerami padi yang berukuran $3 \times 3$ meter lapis demi lapis. Setiap lapisan dipadatkan dengan cara diinjak-injak dengan tebal setiap lapisan $\pm 30 \mathrm{~cm}$. Urea dan air terlebih dahulu dicampur dalam ember hingga larut, selanjutnya molases dan MA-11 ditambahkan kedalam larutan hingga seluruh bahan tercampur rata di dalam ember. Selanjutnya larutan disiramkan disetiap permukaan lapisan tumpukan jerami yang telah dipadatkan dengan cara dipercik sedikit demi sedikit. Tumpukan jerami selanjutnya dibiarkan selama 21 hari untuk proses fermentasi, dan setelah 3 minggu jerami padi amoniasi dievaluasi secara fisik (organoleptik) dan kimiawi.

\subsection{Evaluasi Kualitas Fisik Dan Kimiawi}

Berdasarkan hasil pengamatan kualitas fisik jerami padi amoniasi secara organoleptik diperoleh:

- Warna Coklat Muda/Kecoklatan. Perubahan warna jerami padi amoniasi dari kuning menjadi warna coklat mengindikasikan bahwa proses fermentasi telah berlangsung. Reksohadiprodjo (1988) menyatakan perubahan warna terjadi pada tanaman yang mengalami proses ensilase yang disebabkan oleh perubahan-perubahan yang terjadi dalam tanaman karena proses respirasi anaerobik yang berlangsung selama persediaan oksigen masih ada hingga gula tanaman habis. Penurunan oksigen diikuti dengan peningkatan kadar $\mathrm{CO}_{2}$ sehingga temperatur pemeraman meningkat 


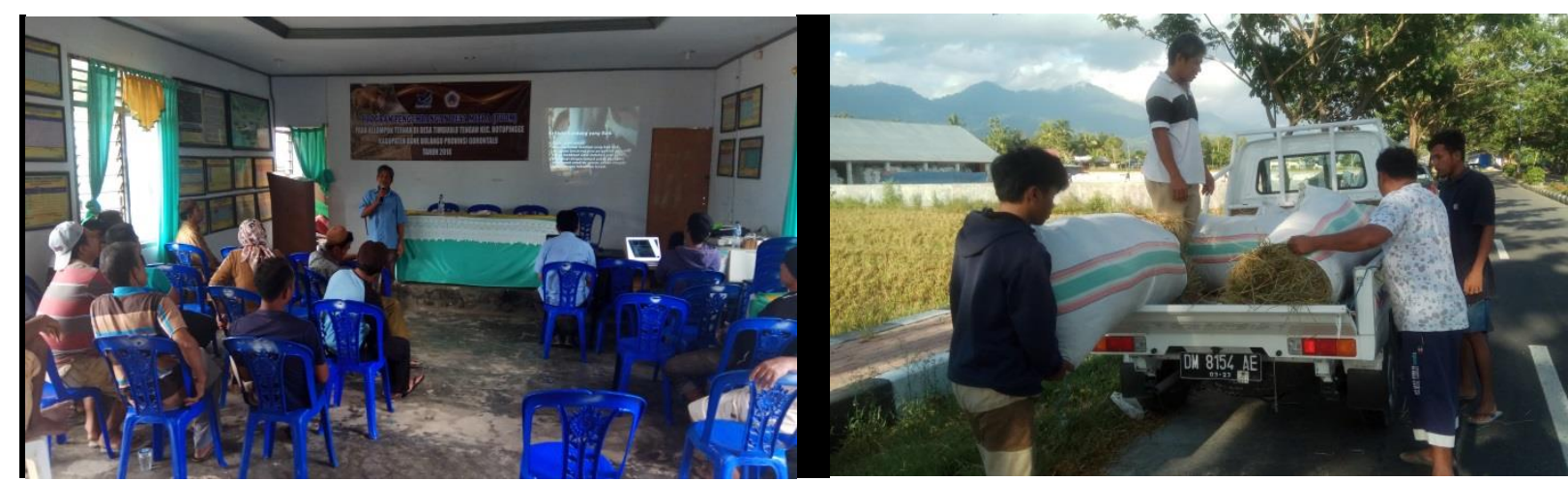

Gambar 1. Pemberian Teori di Aula Kantor Desa dan Pengangkuatan Jerami Padi Amoniasi Dari Lahan Sawah

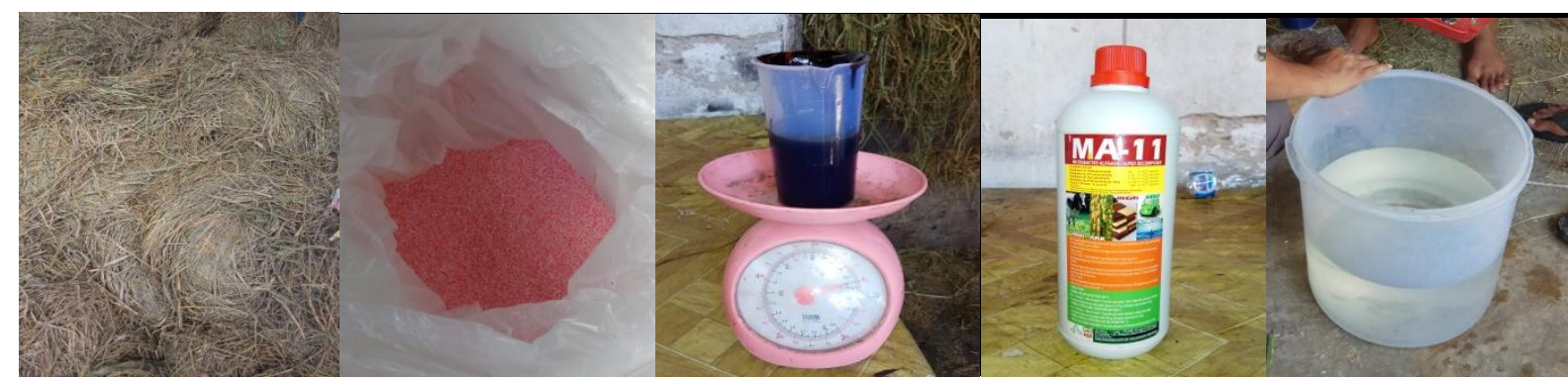

Gambar 2. Bahan Bahan Untuk Pembuatan Jerami Padi Amoniasi. Dari Kiri: Jerami Padi, Urea, Molases, Microorganism Effective-11 (MA-11) dan Air

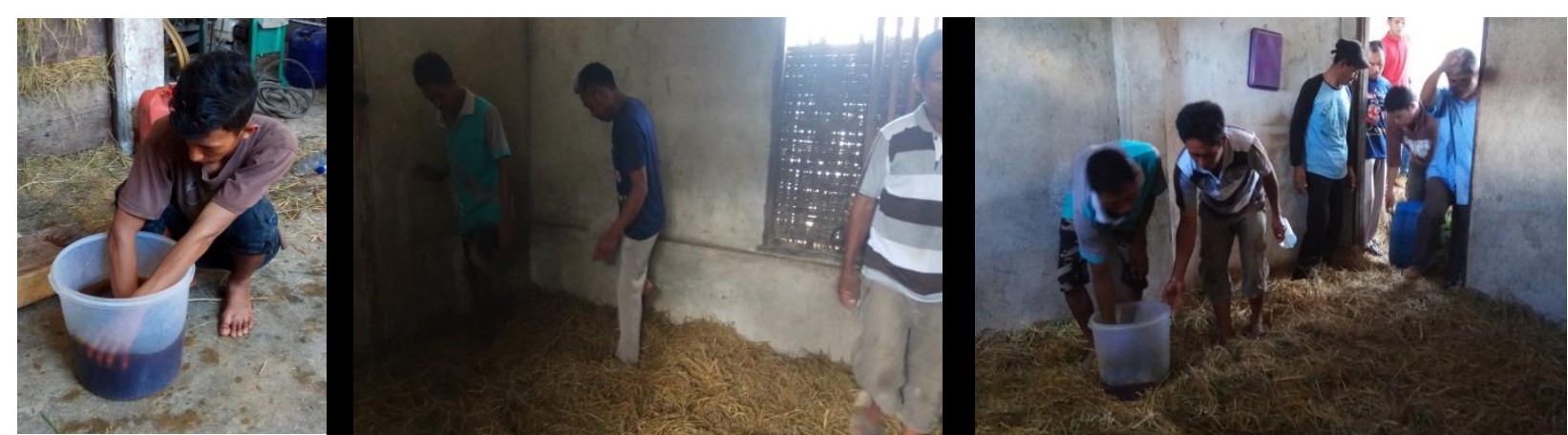

Gambar 3. Melarutkan Seluruh Bahan Dalam Ember Berisi Air. Jerami Padi Yang Akan Diamoniasi Dipadatkan Dengan Cara Diinjak, Selanjutnya Larutan Disiram Diatas Jerami Dengan Cara Dipercik

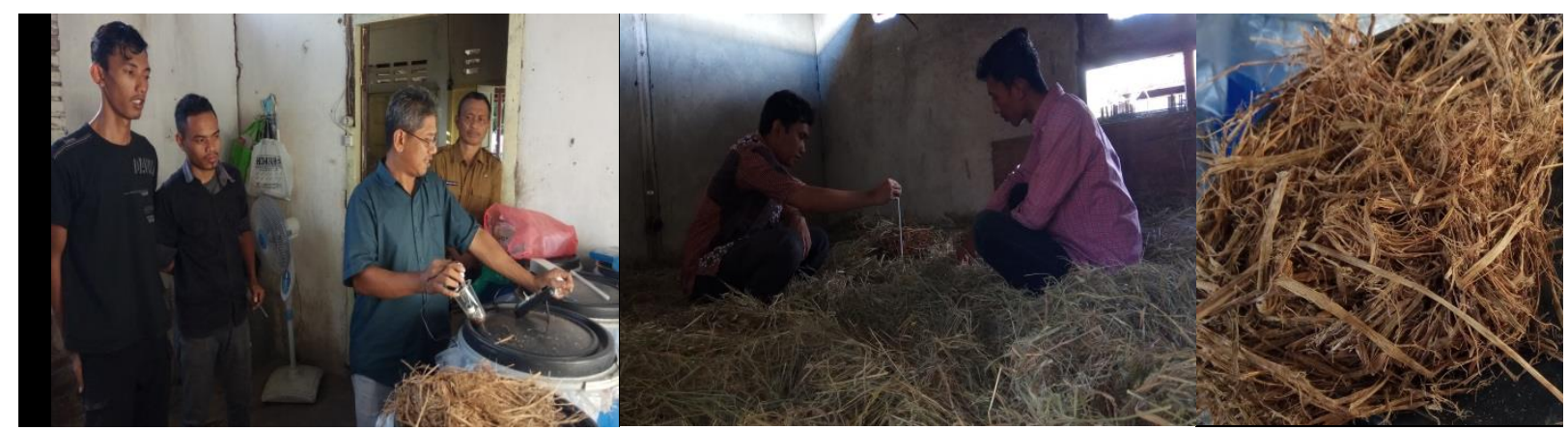

Gambar 4. Setelah 21 Hari, Jerami Padi Secara Fisik (Warna, Bau, Tekstur, Ph, Suhu, Dan Keberadaan Jamur) Dan Kimia (Kandungan Proksimat) Di Laboratorium Nutrisi Dan Makanan Ternak UNHAS

- Bau amoniak. Timbulnya bau amonia disebabkan suasana basa selama proses amoniasi mengakibatkan urea yang memiliki rumus $\mathrm{CO}\left(\mathrm{NH}_{2}\right)_{2}$ diubah menjadi $\mathrm{NH}_{3}$ (amonia) sehingga terserap oleh jerami padi dan menimbulkan bau amonia yang menyengat. Bau yang kurang kuat/lemah mengindikasian proses amoniasi jerami padi tidak berlangsung dengan baik, tidak efisien bahkan gagal. Penyebab bau yang kurang karena jumlah urea yang digunakan terlalu sedikit, silo tidak tertutup rapat sehingga sebagian besar amonia yang terbentuk menguap dan tidak terikat oleh jerami padi, urea belum atau tidak terhidrolisis secara sempurna, kurangnya jumlah air yang digunakan atau kelembaban dalam silo, kurangnya 
bakteri ureolitik atau sumber urease dalam jerami padi yang digunakan (Marjuki, 2013)

- Tekstur halus. Tekstur jerami padi amoniasi yang lembut dan halus disebabkan ikatan lignin, sellulosa, dan silika pada dinding jerami lepas. Semakin lama proses fermentasi maka tekstur jerami padi amoniasi akan semakin lembut dan lunak sehingga lebih mudah dicerna oleh mikroba rumen. Menurut DitJenNak (2011) kriteria amoniasi yang baik adalah berwarna kecoklat-coklatan, kering,jerami amoniasi lebih lembut dibandingkan jerami asalnya

- $\mathrm{Ph} 7,8$, Nilai pH 7,8 yang yang merupakan $\mathrm{pH}$ netral tidak berbeda jauh dengan hasil penelitian Bata (2008) bahwa jerami padi yang diberi urea dan molases $15 \%$ adalah antara $7-5,5$

- Suhu $43,66^{\circ} \mathrm{C}$. Proses hidrolisis urea menjadi amonia berlangsung dengan baik pada kisaran suhu $30-60^{\circ} \mathrm{C}$. Kecepatan hidrolisis tersebut akan berlipat atau turun dua kali lipat pada setiap peningkatan atau penurunan suhu sebesar $10^{\circ} \mathrm{C}$ (Marjuki, 2013)

- Ditemukan sedikit fungi/jamur pada bagian atas dan pinggir tumpukan namun dibagian tengah tidak ada. Jamur yang ditemukan pada tumpukan jerami padi amoniasi disebabkan fermentasi yang digunakan secara terbuka (aerob) sehingga bagian pinggir dan atas yang bersentuhan langsung dengan udara ditumbuhi jamur.

Tabel 1. Hasil Pengujian Fisik dan Kimiawi Jerami Padi Amoniasi

\begin{tabular}{llc}
\hline NO & Metode Pengujian & $\begin{array}{c}\text { Hasil Yang } \\
\text { Diperoleh }\end{array}$ \\
\hline I & Kualitas Fisik & Coklat \\
& Warna & Amoniak \\
& Bau & Halus \\
& Tekstur & 7,8 \\
& pH & 43,66 \\
& Suhu & Sedikit \\
\hline Fungi & Kualitas Kimia (\%) & 8,09 \\
& Air & 5,65 \\
& Protein & 1,99 \\
& Lemak & 33,60 \\
& Serat Kasar & 31,66 \\
& Bahan Ekstrak Tanpa & \\
& Nitrogen (BETN) & 27 \\
& Abu & \\
\hline
\end{tabular}

Berdasarkan hasil analisis proksimat (Tabel 1) pada jerami padi amoniasi diperoleh kadar air 8,09\%, protein $5,65 \%$, lemak $1,99 \%$, serat kasar $33,60 \%$, BETN $31,66 \%$, dan abu $27 \%$. Kandungan nutrisi dari hasil fermentasi lebih tinggi dibandingkan dengan jerami padi tanpa perlakuan yaitu protein kasar 4,31\% (Syamsu et al, 2006), Serat Kasar $>34 \%$ (Sutrisno et al, 2006), lemak kasar 3,88\%, Abu 21,35\%, dan bahan organik 69,94\% (Preston, 2005). Amoniasi jerami padi dengan menggunakan urea mampu meningkatkan protein kasar ransum karena urea mengandung sekitar $45 \%$ Nitrogen atau equivalen dengan 284\% Protein Kasar (Puastuti, 2010).

\section{Kesimpulan}

Amoniasi jerami padi dapat menjadi solusi untuk mengatasi kekurangan hijauan pakan untuk sapi potong di Desa Timbuolo Tengah. Kualitas fisik jerami padi yang diamoniasi adalah warna coklat muda/kecoklatan, bau amoniak, tekstur halus, $\mathrm{Ph} 7,8$, Suhu 43,66 ${ }^{\circ} \mathrm{C}$, dan ditemukan sedikit fungi/jamur. Hasil analisis proksimat diperoleh kadar air 8,09\%, protein 5,65\%, lemak 1,99\%, serat kasar 33,60\%, Bahan Ekstrak Tanpa Nitrogen (BETN) 31,66\%, dan abu 27\%. Jerami padi yang diamoniasi dengan urea memiliki kualitas yang lebih tinggi dibanding jerami padi tanpa amoniasi. Kegiatan ini telah meningkatkan pengetahuan dan keterampilan warga desa Timbuolo Tengah dalam membuat jerami padi amoniasi. Pengetahuan yang telah diperoleh diharapkan dapat digunakan untuk mengatasi problem keterbatasan pakan sapi baik kualitas maupun kuantitasnya, sehingga produktivitas sapi potong maupun kesejahteraan warga setempat dapat meningkat.

\section{DAFTAR PUSTAKA}

Achmadi, J. 2012. Aspek Komparatif Nutrisi Ternak Monogastrik dan Ruminansia. Penerbit Universitas Diponegoro, Semarang.

Ahmed, A., Khan, M.J., Shahjalal, M. and Islam, K.M.S., 2002. Effects of Feeding Urea and Soybean Meal Treated Rice Straw on Digestibility of feed Nutrient and Growth Performance of Bull Calves. Asian-Aus. J. Anim-Sci 15 : 522-527.

Anonimous. 1982. Inventarisasi limbah pertanian Jawa dan Bali. Fakultas Peternakan UGM dan Direktorat Bina Produksi. Ditjen Peternakan.

Aprintasari, R., C.I. Sutrisno dan B.I.M. Tampoeboelon. 2012. Uji Total Fungi Dan Organoleptik Pada Jerami Padi Dan Jerami Jagung Yang Difermentasi Dengan Isi Rumen Kerbau. Animal Agriculture Journal, Vol. 1. No. 2, 2012, p 311 321.

Bata, M. 2008. Pengaruh Molases Pada Amoniasi Jerami Padi Menggunakan Urea Terhadap Kecernaan Bahan Kering dan Bahan Organik In Vitro. Jurnal Agripet : Vol (8) No. 2: 15-20

Badan Pusat Statistik (BPS) Bone Bolango. 2017. Bone Bolango Dalam Angka 2017. BPS Bone Bolango. Bone Bolango

Direktorat Jenderal Peternakan dan Kesehatan Hewan. 2011. Pedoman Umum Pengembangan Lumbung Pakan Ternak. ditjennak.pertanian.go.id/download.php?. Download Tanggal 27 Oktober 2015.

Hidanah, S. 2007. Isolasi Bakteri dan Jamur Selulolitik sebagai Inokulum Untuk Meningkatkan Jerami Padi dan Produktivitas Domba. Disertasi Pascasarjana Universitas Airlangga Surabaya

Marjuki, 2013. Peningkatan Kualitas Jerami Padi Melalui Perlakuan Urea Amoniasi. Fakultas Peternakan Universitas Brawijaya Malang

Martawidjaja, M. 2003. Pemanfaatan Jerami Padi Sebagai Pengganti Rumput Untuk Ternak 
Ruminansia Kecil. Wartazoa Vol. 13 No. 3 Th. 2003

McDonald, P., Edwards, R.A. and Greenhalg, J.P.D., 2002. Animal Nutrition. sixth Ed. Prentice hall. Gosport. London. Pp : 427-428.

Preston, L. 2005. Feed Composition Tables. http://BeefMag.com/Mag/Beef Feed. Composition Tables.

Puastuti, W. 2010. Urea Dalam Pakan Dan Implikasinya Dalam Fermentasi Rumen Kerbau. Seminar Dan Lokakarya Nasional Kerbau 2010

Puastuti, W. dan I.W. Mathius. 2008. Respon domba jantan muda pada berbagai tingkat substitusi hidrolisat bulu ayam dalam ransum. JITV 13(2): $95-102$.

Pupuk Sriwidjaja (Pusri) Palembang. 2018. Pupuk Urea. http://www.pusri.co.id/ina/urea-tentang-urea/. Didownload pada 20/7/2018

Sebayang, F. 2006. Pembuatan Etanol Dari Molase Secara Fermentasi Menggunakan Sel Saccharomyces cerevisiae yang Terimobilisasi Pada Kalsium Alginat. Jurnal Teknologi Proses. Departemen Kimia, Fakultas MIPA, Universitas Sumatera Utara: 6874. ISSN 1412-7814

Syamsu, J.A., Natsir, A., Siswadi., Abustam, E., Hikmah, Nurlaelah, Muliwarni, Setiawan, A.H., dan Arasy, A.M. 2006. Limbah Tanaman Pangan sebagai Sumber Pakan Ruminansia: Potensi dan Daya Dukung di Sulawesi Selatan. Makassar: Yayasan Citra Emulsi dan Dinas Peternakan Propinsi Sulawesi Selatan

Reksohadiprodjo, S. 1998. Pakan Ternak Gembala. BPFE, Yogyakarta.

Utomo, R.S. Reksodiprodjo, B.P. Widyobroto, Z. Baachrudin and B. Suhartanto. 1998. Determination of nutrients digestibility, rumen fermentation parameters, and microbial protein concentration on Onggole Crossbred cattle fed rice straw. Bull. Of Anim. Sci. Supplement edition. Faculty of Animal Science, Gadjah Mada University. pp. 82-88.

Van Soest, P.J. 1982. Effect of environment and quality fibre on the nutritive value of crop residues. In: Plant Breeding and The Nutritive Value of Crop Residues. REED, J.D., B.S. CAPPER and P.J.H. (Eds.). Adis Ababa, Ethioppia. ILCA. pp. 71-96

Winugroho, M., B. Bakri, T. Panggabean dan N.G. Yaters. 1983. Pengaruh panjang pemotongan dan perlakuan kimia terhadap jumlah konsumsi dan daya cerna jerami padi. pros. Pertemuan Ilmiah Ruminansia Besar. Puslitbangnak, Bogor. hlm. 16-20. 